PRZEGLĄD NAUK HISTORYCZNYCH 2020, R. XIX, NR 2

https://doi.org/10.18778/1644-857X.19.02.08

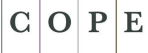

$\underset{\text { JM13705 }}{\text { Member since }} 2018$

ARIEL ORZEŁEK

Uniwersytet Mari Curie-Sklodowskiej w Lublinie*

(iD) https://orcid.org/0000-0001-5360-464X

\title{
Spory o romantyzm i realizm historyczny na lamach prasy polskich katolików świeckich w latach 1945-1953
}

Streszczenie. Polscy katolicy świeccy w swej prasie w pierwszych latach powojennych częstokroć zajmowali się oceną polskich zrywów narodowych i wnioskami, jakie $z$ nich można było wyciągnąć dla teraźniejszości i przyszłości. Narracje te nie były jednak tylko deprecjonujące antyrosyjskie powstania, ale starały się zrozumieć motywacje ich uczestników. Podnoszono często konieczność uwzględnienia przez politycznych realistów „realizmu względem uczuć narodu”, ale i kształtowania postaw w kierunku racjonalnej oceny zjawisk politycznych. Zdarzały się teksty pozostające $\mathrm{w}$ nurcie skrajnie romantycznym, ale i skrajnie realistycznym oraz pacyfistycznym. Prezentowane dyskusje i polemiki wynikały zarówno $z$ rozczarowania wynikami wojny, jak i niepowodzenia własnych koncepcji. Duży wpływ na ich formułowanie miała też świadomość strat, jakie naród polski poniósł w ostatnim czasie na skutek realizowania powstańczej polityki oraz przekonania o tym, że kolejny zryw może przynieść katastrofalne już dla zbiorowości skutki. Najbardziej charakterystyczna dla prowadzonego między realistami a romantykami sporu o samą definicję tych pojęć, dyskusja „o Monte Cassino" na łamach "Tygodnika Powszechnego”, dowiodła pewnego ideowego zagubienia publicystów, rozpaczliwie niejako chcących odnaleźć się w nowej rzeczywistości.

Słowa kluczowe: katolicy świeccy, myśl polityczna, Polska Ludowa, publicystyka, realizm polityczny, romantyzm.

* Wydział Humanistyczny, Instytut Historii, Katedra Metodologii i Badań nad XX-XXI w., e-mail: ariel.k.orzelek@gmail.com 
Tak zauważał Adam Bromke, historia polskiej myśli politycznej ostatnich kilku wieków to dzieje sporu między romantyzmem a politycznym realizmem ${ }^{1}$. Druga wojna światowa miała zasadniczy wpływ na upowszechnienie się postaw realistycznych i pozytywistycznych, zarówno wśród intelektualistów, jak i w masach. $\mathrm{O}$ ile to ostatnie pod względem naukowym jest $\mathrm{w}$ zasadzie nieuchwytne, a świadczyć o tym moga jedynie takie symptomy, jak ograniczony zasięg konspiracji antykomunistycznej czy postawa Polaków w październiku 1956 r., o tyle refleksja badawcza nad polska powojenną myśla polityczna z łatwościa pozwala dowieść tej pierwszej tezy. Ksawery Pruszyński już w 1941 r. w memoriale do rządu gen. Władysława Sikorskiego pisał o konieczności ułożenia stosunków $z$ Rosją, bazując na uznaniu jej prymatu w powojennej Europie $^{2}$. Wyraził to rok później w głośnym artykule Wobec Rosji ${ }^{3}$. W 1944 r. opublikował w Londynie, a dwa lata później w Polsce Margrabiego Wielopolskiego, będącego zarówno esejem biograficznym, jak i pamfletem na polski romantyzm, głoszacym konieczność zarzucenia koncepcji insurekcyjnych ${ }^{4}$. W tym samym czasie jego przyjaciel Aleksander Bocheński pracował nad krytycznymi dla polskiej historiografii Dziejami głupoty $w$ Polsce, które wydał w 1947 r. ${ }^{5}$, wzbudzając burzliwa dyskusję, wynikająca $z$ jego radykalnego $\mathrm{w}$ formie i treści rozrachunku $\mathrm{z}$ polskimi tradycjami romantycznymi ${ }^{6}$. W 1946 r. Edmund Osmańczyk, pisząc o współczesnych relacjach polsko-niemiecko-rosyjskich, jednoznacznie

${ }^{1}$ A. Bromke, Poland's politics. Idealism vs Realism, Cambridge 1967. O problemach $z$ definiowaniem realizmu politycznego, także w polskich warunkach, por. P. Kimla, Historycy-politycy jako źródło realizmu politycznego. Tukidydes - Polibiusz - Machiavelli, Kraków 2009, passim; J. K1oczkowski, Oblicza polskiego realizmu politycznego, [w:] Realizm polityczny. Przypadek Polski. Wybór tekstów, red. J. Kloczkowski, Kraków 2008, s. 7-15.

${ }^{2}$ K. Pruszyński, ZSRR wobec wojny i sprawy polskiej. Nowe źródła informacyjne w ZSRR, Instytut Polski i Muzeum im. gen. Sikorskiego w Londynie, Zespół Prezydium Rady Ministrów - Kancelaria, sygn. PRM.K.23, k. 5-11.

${ }^{3}$ K. Pruszyński, Wobec Rosji, „Wiadomości Polskie” 1942, nr 40, s. 1.

${ }^{4}$ K. Pruszyńs ki, Margrabia Wielopolski, Warszawa 1946.

${ }^{5}$ A. Bocheński, Dzieje głupoty w Polsce. Pamflety dziejopisarskie, Warszawa 1947 .

${ }^{6}$ Por. A. Orzełek, Recepcja publicystyczna „Dziejów głupoty w Polsce. Pamfletów dziejopisarskich" Aleksandra Bocheńskiego, "Przegląd Nauk Historycznych" 2018, R. XVII, nr 2, s. 203-223; E. Kristanova, Ksiażka na łamach katolickich czasopism społeczno-kulturalnych w Polsce w latach 1945-1953, Łódź 2012, s. 404. 
wskazywał na konieczność oparcia polityki polskiej na Moskwie ${ }^{7}$. Wszyscy trzej autorzy nie poruszali się w schemacie myślowym komunizmu, wywodząc swą motywację $z$ przesłanek realistycznych, a nie ideologicznych.

Znamienne też, że grono radykalnie romantycznych działaczy Konfederacji Narodu w 1945 r. doszło do wniosku o konieczności zupełnej redefinicji swych dotychczasowych koncepcji. Ci, którzy jeszcze w 1943 r. chcieli budować na gruzach Niemiec i Związku Sowieckiego Imperium Słowiańskie, w którym hegemonem byłaby Polska rozciągająca się od ujścia Odry aż po Odessę ${ }^{8}$, dwa lata później postulowali konieczność ugody z Sowietami. Aresztowany w 1944 r. Bolesław Piasecki grał z pewnością o życie, proponując gen. Iwanowi Sierowowi utworzenie środowiska katolików współpracujących $\mathrm{z}$ komunistami, twierdził jednak, że klęska jego wojennych i przedwojennych koncepcji skłoniła go do zmiany zapatrywań ${ }^{9}$. Podobnie swój tok myślenia określali ci, którzy pozostali na wolności i często w konspiracji: Jerzy Hagmajer, Mieczysław Kurzyna, Wojciech Kętrzyński czy Dominik Horodyński. Klęska koncepcji II Rzeczypospolitej, „wielkiej Polski”, zdecydowane zwycięstwo Sowietów w wojnie i brak wiary w pomoc Zachodu, ale też troska o „substancję biologiczną narodu” i losy Kościoła, skuteczność propagandy władz głoszącej, że budują lepszą, lewicową i patriotyczną Polskę, a także chęć ułożenia życia prywatnego zniechęcały do dotychczasowej działalności ${ }^{10}$. Powodowało to,

7 E. Osmańczyk, Sprawy Polaków, Katowice 1946.

8 Por. mapę imponujacych ambicji terytorialnych „Imperium Słowiańskiego”: Imperium Słowiańskie. Mapa wydana przez Konfederację Narodu Organizację Drużyn Imperium Słowiańskiego, Warszawa 1 X 1941, Studium Polski Podziemnej w Londynie, Zespół Ministerstwo Spraw Wewnętrznych, sygn. MSW.023_1, k. 104.

9 A. Dudek, G. Pyte1, Bolesław Piasecki. Próba biografii politycznej, Londyn 1990, s. 150-156, 167; J. Engelgard, Bolesław Piasecki 1939-1956, Warszawa 2015, s. 46-69, 159-164; M.S. Kunicki, Between the brown and the red. Nationalism, Catholicism, and communism in twentieth-century Poland. The politics of Bolesław Piasecki, Ohio 2012, s. 77-98; L. Blit, The Eastern Pretender. Boleslaw Piasecki. His life and times, London 1965, s. 101-130; A. J a szczuk, Ewolucja ideowa Bolesława Piaseckiego 1932-1956, Warszawa 2005, s. 80-81; A. Fris zke, Między wojna a więzieniem 1945-1953. Młoda inteligencja katolicka, Warszawa 2015, s. 59-68; N. Pi etrow, Stalinowski kat Polski Iwan Sierow, Warszawa 2013, s. 50-53; J. M aj ch row s ki, Geneza politycznych ugrupowań katolickich. Stronnictwo Pracy, grupa „Dziś $i$ Jutro”, Paris 1984, s. 154-155; Z. Przetakiewicz, Od ONR-u do PAX-u (wspomnienia), Warszawa 1994, s. 66-69, 81-83.

10 Jak doszło do powstania „Dziś i Jutro”. Dyskusja na łamach „Życia i Myśli” nr II 21975 z udziałem: Aleksander Bocheński, Jan Dobraczyński, Jerzy 
jak opisuje Mariusz Mazur w swej ostatniej książce, odchodzenie $z$ konspiracji, a jak wskazywali sami zainteresowani, także poszukiwanie nowych dróg politycznego działania ${ }^{11}$. Nie oznacza to jednak, że odrzucili oni swa romantyczna partyzancka tradycję. Chociaż zerwali $z$ radykalnym narodowym szowinizmem, to jednocześnie za ważna i cenną uznawali pamięć o poległych konspiratorach i partyzantach, w tym tych $z$ ich kręgu ideowego. Znamienne, że „Dziś i Jutro" opublikowało już w Polsce Ludowej na swych łamach wiersz Andrzeja Trzebińskiego Wymarsz Uderzenia, kończący się słowami „Imperium gdy powstanie, to tylko $z$ naszej krwi!" 12 .

Stanisław Stomma w 1946 r. opublikował głośny esej o minimalizmie i maksymalizmie koncepcji politycznych polskich katolików, przestrzegając przed zgubną wiarą w możliwość osiagnięcia celów ambitnych i wielkich, narażających na szwank istniejące koncesje $^{13}$. Refleksja ta stała się jednym $z$ istotnych elementów katolickiego powojennego neopozytywizmu ${ }^{14}$. Nie był on oportunizmem. Jak wskazał Piotr Kimla w swej publikacji dotyczacej realizmu

Hagmajer, Mieczysław Kurzyna, Romuald Szpor” [wersja robocza maszynopisu, tekst nigdy nieopublikowany na łamach prasy Stowarzyszenia „PAX”], Archiwum Katolickiego Stowarzyszenia Civitas Christiana w Warszawie, Akta Aleksandra Bocheńskiego, sygn. VII A-305, k. 1-27.

${ }_{11}$ M. Mazur, Antykomunistycznego podziemia portret zbiorowy 1945-1956. Aspekty mentalno-psychologiczne, Lublin-Warszawa 2019, s. 39-88, 105-112.

12 J.H. [J. Hagmajer], Dr. Jekyll imr. Hyde, „Dziś i Jutro” 1946, R. II, nr 9 (15), s. 5; id e m Halina Piasecka („Halina”), „Dziś i Jutro” 1946, R. II, nr 43 (49), s. 5; idem, Włodzimierz Pietrzak („Balk”), ibidem, s. 5; Kiejstut. Z-ca Komendanta Konfederacji Narodu [J. Hagmajer], [List do Redakcji „Dziś i Jutro”], „Dziś i Jutro” 1946, R. II, nr 7 (13), s. 5; Z. Przetaki ew icz, ONR - Konfederacja Narodu - „Dziś i Jutro”, „Dziś i Jutro” 1947, R. III, nr 14-15 (71-72), s. 7; S. Zi e mbicki, Pokolenie dramatyczne, „Dziś i Jutro” 1946, R. II, nr 5 (11), s. 4; A. Łomień-Trzebiński, Wymarsz Uderzenia, „Dziś i Jutro” 1946, R. II, nr 6 (12), s. 1.

${ }_{13}$ S. S to m ma, Maksymalne i minimalne tendencje społeczne katolików, „Znak” 1946, nr 3, s. 257-275.

${ }^{14}$ B. Bankowicz, Neopozytywizm Znaku: próba legalizmu motywowana realizmem, [w:] e a d e m, A. Du d ek, Ze studiów nad dziejami Kościoła i katolicyzmu $w$ PRL, Kraków 1996, s. 37-52; R. Graczyk, Spory ideowo-polityczne $w$ kregu „Tygodnika Powszechnego" w latach 1945-1953, [w:] Temat polemiki: Polska. Najważniejsze polskie spory ideowo-polityczne, red. J. Kloczkowski, Kraków 2012, s. 315-333; R. G ra czyk, Stanowisko katolików świeckich z „Tygodnika Warszawskiego", "Tygodnika Powszechnego" oraz "Dziś $i$ Jutro" wobec władzy i ideologii komunistycznej w latach 1945-1948, [w:] Polskie wizje i oceny komunizmu po 1939 roku, red. R. Łatka, B. Szlachta, Kraków 2015, s. 235-239; R. Matyja, Państwowość PRL w polskiej refleksji politycznej lat 1956-1980, Kraków-Nowy Sącz 2007, s. $105-119$. 
politycznego, jego granica jest zawsze wierność nadrzędnym wartościom, imponderabiliom ${ }^{15}$. Kompromis w ich naruszeniu nie jest możliwy. Dowiódł tego Stomma i środowisko „Tygodnika Powszechnego" w 1953 i 1976 r., a także grupa „Tygodnika Warszawskiego”, której pismo zostało zamknięte, a jej członkowie represjonowani.

Celem tego tekstu jest analiza narracji publicystycznych wyrażajacych ideowe poszukiwanie polskich intelektualistów niebędących komunistami, a mających możliwość zabrania głosu w powojennym dyskursie publicznym, dotyczących oceny polskich powstań narodowych i w ogóle wyborów polityki polskiej w ostatnich 200 latach. Toczyła się ona na łamach „Dziś i Jutro” i „Słowa Powszechnego” - pism grupy Bolesława Piaseckiego, „Tygodnika Powszechnego” oraz chadeckiego „Tygodnika Warszawskiego”. Cezurę początkową, rok 1945, wyznacza założenie "Tygodnika Powszechnego” oraz „Dziś i Jutro”. Cezurę końcowa - zamknięcie niezależnego „Tygodnika Powszechnego" i zmonopolizowanie po roku 1956 katolickiej refleksji intelektualnej przez Stowarzyszenie „PAX”, wykluczajace jakąkolwiek wymianę poglądów. Istotną datą jest też rok 1948 i zaostrzenie politycznego kursu, zamykające końcowy proces walki z polityczną opozycją i wszelkimi nurtami niezależnymi od komunistów. W dziejach środowisk katolickich rok ten oznacza rozłam na nurt zdecydowanie afirmujący rzeczywistość (grupa Piaseckiego) oraz środowisko „emigrujace” do tematyki historycznej i kulturalnej („Tygodnik Powszechny” i „Znak”). Ci, którzy wybrali bezkompromisowość, redaktorzy „Tygodnika Warszawskiego”, jak wspomniałem, zaczęli wówczas płacić wysoką cenę za swoje poglądy.

\section{Dzieje rozbiorowe}

Spór o romantyzm i realizm w polityce polskiej w dużej mierze dotyczył epoki napoleońskiej i wielkich powstań narodowych. Był on de facto konstytutywny dla myśli realistycznej w Polsce - prowadzony niejako na bieżaco tych historycznych wydarzeń, wpłynął na postrzeganie polskich problemów geopolitycznych w póżniejszych epokach.

Kluczowe miejsce w refleksji podjętej w pierwszych powojennych latach zajmowało stanowisko Aleksandra Bocheńskiego. Wydawać by się mogło, że autor Dziejów głupoty..., z zaciekłością zwalczający historyków dokonujacych apologii błędnych jego zdaniem decyzji,

15 P. Kimla, op. cit., passim. 
krytykę swą rozciągnie na żołnierzy i powstańców. Publicysta rozróżniał jednak te dwie kwestie, dając temu wyraz w opublikowanym na łamach „Tygodnika Powszechnego” artykule zatytułowanym O dyskusji nad Monte Cassino. Nawiazywał on do prowadzonych na łamach prasy młodzieżowej sporów na temat sensu heroizmu wojennego. Antycypował niejako późniejsze burzliwe dyskusje o „bohaterszczyźnie”. Oceniając epokę napoleońska, jej skutki dla sprawy polskiej Bocheński uznawał za korzystne, ale obiektywnie irracjonalne (nic nie wskazywało jeszcze kilka lat przed zdobyciem władzy przez Bonapartego, że Francuzi pobija wielkie mocarstwa kontynentalne, zapuszczą się na ziemie polskie i dokonają odbudowy polskiej państwowości). Niemniej udział Polaków po stronie cesarza był wypełnieniem zobowiązań sojuszu, doprowadził do odnowienia polskiego militaryzmu, dowiódł jego wartości w świecie, co miało niebagatelne znaczenie po klęsce Napoleona. Chociaż w Dziejach głupoty... Bocheński pisał o „przeklętym psychologicznym dziedzictwie epoki Legionów", które kazało Polakom widzieć zawsze sojusznika we Francuzach i wierzyć w ich pomoc w beznadziejnych sytuacjach, i dowodził, że to książę Adam Jerzy Czartoryski miał rację, starając się skłonić Polaków jeszcze w $1811 \mathrm{r}$. do przejścia na stronę cara Aleksandra I, to szarżę pod Somosierra, będąca symbolem polskiego poświęcenia w służbie cesarzowi Napoleonowi, uznawał za wyczyn potrzebny i chwalebny. Zasadnicza teza, jaka głosił, było przekonanie, że żołnierze nie powinni dyskutować nad politycznym sensem rozkazów, jakie otrzymuja i dlatego też nie moga być krytykowani za ich wykonywanie. Szkody wynikłe $z$ naruszenia dyscypliny wojskowej uznawał za o wiele bardziej zgubne niż wywołane wykonaniem najbardziej nawet bezrozumnych rozkazów. Uważał bowiem, że możliwość kwestionowania zwierzchnictwa politycznego prowadziłaby do zupełnego rozprężenia dyscypliny ${ }^{16}$.

Inni publicyści, a raczej historycy publikujący na łamach "Tygodnika Powszechnego" w kwestii wczesnych dziejów rozbiorowych byli jeszcze dość tradycyjni. Stanisław Pigoń w „Tygodniku Powszechnym" pisząc o Tadeuszu Kościuszce, nie przeczył, że przegrał on wojnę w sensie politycznym, lecz wygrał walkę o „duszę ludu polskiego", a to było warunkiem skutecznej walki o niepod-

16 A. Bocheński, O dyskusji nad Monte Cassino, „Tygodnik Powszechny” 1946, R. II, nr 45 (86), s. 1, 4-5. Por. id e m, Dzieje głupoty..., passim; E. Kris tanova, op. cit., s. 135 . 
ległość w dobie nowoczesnej ${ }^{17}$. Adam Skałkowski wskazywał, że epoka napoleońska nie była zmarnowanym dla Polski czasem, przynosząc odrodzenie wojskowości i form państwowości polskiej ${ }^{18}$.

Przede wszystkim jednak, gdy chodzi o czasy dawniejsze, publicystów zajmowała sprawa oceny powstań listopadowego i styczniowego. Wojciech Kętrzyński, bliski Bolesławowi Piaseckiemu, krytykował w „Dziś i Jutro” upraszczanie problematyki teza, że winna upadku zrywu lat 1830-1831 jest „rodzima reakcja”. A przecież to dzięki działalności takich „reakcjonistów”, jak Ksawery Drucki-Lubecki Królestwo Polskie miało w ogóle pieniądze na prowadzenie wojny $z$ Rosja. Adiutant Piaseckiego przekonany był, w przeciwieństwie do marksistów, że insurekcja nie miała szans na zwycięstwo ze względu na sytuację międzynarodowa - nie tylko rosyjska przewagę, lecz także to, że Prusy nie pogodziłyby się nigdy $z$ niepodległością Polski. Pomoc „ludów” była zaś w tym wypadku bezwartościowa, bo dyplomatyczna. Gloryfikacja powstania listopadowego i romantyzmu jego sprawców oznaczała w istocie gloryfikację tych samych motywów, które legły już wówczas u podstaw szkodliwej jego zdaniem decyzji o rozpoczęciu walki powstańczej w Warszawie latem 1944 r. ${ }^{19}$

Kętrzyński, pisząc $z$ kolei recenzję Margrabiego Wielopolskiego, podkreślał patriotyzm tytułowego bohatera książki Pruszyńskiego. Był jednak w swej optyce jeszcze niejednoznaczny. $Z$ jednej strony sugerował, że do uznania wielkości Margrabiego Polacy musieli dojrzeć, z drugiej twierdził, że źle się stało, iż Wielopolski był dla Pruszyńskiego jedynie pretekstem do afirmacji współczesnej ugody polsko-rosyjskiej. Był wszak Naczelnik Rządu Cywilnego Królestwa politykiem, który chciał reprezentować naród, a choć przegrał, zostawił po sobie wzór realnego myślenia politycznego. Jak się jednak okaże, Kętrzyński, jak i inni, zarzucali „Wielopolskim” to, że zlekceważyli pewne prawidła tego sposobu pojmowania polityki ${ }^{20}$.

Stefan Kieniewicz, publikując w "Tygodniku Powszechnym” recenzję Margrabiego..., podkreślał konserwatyzm społeczny Wielopolskiego i jego błędy, spośród których za najważniejsze uznawał

17 S. Pigoń, O największym zwycięstwie Tadeusza Kościuszki, „Tygodnik Powszechny” 1946, R. II, nr 12 (53), s. 1.

18 A.M. Skałkowski, Somosierra, „Tygodnik Powszechny” 1947, R. III, nr 24 (117), s. 7 .

19 W. Kętrzyńs ki, Na tle powstania listopadowego, „Dziś i Jutro” 1946, R. II, nr 1 (7), s. 4.

${ }^{20}$ I d e m, Problem Wielopolskich, „Dziś i Jutro” 1946, R. II, nr 28 (34), s. 2-3. 
lekceważenie kwestii społecznej i podjęcie wojny z opinią publiczną oraz - co gorsza $-z$ uczuciami narodu. Nie mógł być, zdaniem wybitnego historyka, Wielopolski wzorcem współcześnie ze względu na odmienne uwarunkowania, w których przyszło mu działać. Czy jednak Kieniewicz zrozumiał zasadniczy sens eseju Pruszyńskiego, czyli apologię ugody polsko-rosyjskiej? A jeśli wbrew pozorom tak, to czy jego recenzja nie była głosem przeciwko jej narzucaniu przy nieliczeniu się $\mathrm{z}$ opinią Polaków? ${ }^{21}$

Powstanie styczniowe oceniała czołówka grupy Piaseckiego bardzo ostro, jako klęskę i „nieprzemyślany czyn”. U jego podstaw legła nie tyle nawet błędna kalkulacja polityczna, co myślenie życzeniowe, pozwalajace wierzyć w pomoc cesarza Napoleona III. Brakowało jednak też powiązania momentu wyboru $z$ chwila natężenia ruchów rewolucyjnych (konstatacji, że były one w stanie pomóc Polakom, już za wishful thinking nie uważano), nie potrafiacc też rozbudzić „ludu polskiego”. Wielopolski drażnił społeczeństwo swa polityka, biali lawirowali, czerwoni bali się stać naprawdę „czerwonymi”. Hołd oddany bohaterom nie mógł oznaczać przyzwolenia na bezrozumne szafowanie krwią ${ }^{22}$. Podobnie rzecz ujmował Kazimierz Studentowicz w „Tygodniku Warszawskim”, wskazując na zupełny brak realizmu decydentów powstań w ocenie sytuacji międzynarodowej ${ }^{23}$. Paweł Jasienica za najgorsza konsekwencję powstań narodowych uznawał utratę fachowej siły zbrojnejej.

Zupełnie inaczej patrzyli na problematykę powstań mniej znani autorzy publikujący na łamach „Dziś i Jutro”. Jeden $z$ nich dowodził, że klęska polityki powstańczej nie była utrata kolejnych szczebli autonomii, lecz ostateczne zanegowanie w narodzie ducha insurekcjonizmu i pchnięcie go na tory polityki ugodowej ${ }^{25}$. Tomasz Zaniec, co prawda, w 1954 r. w cyklu szkiców o Wielopolskim deprecjonował nurt realistyczny jako ugodowy i zaprzańczy, idący w poprzek narodowowyzwoleńczym dążeniom Polaków i dążący jedynie do „restauracji szlacheckiego państwa buforowego”. Wielo-

${ }^{21}$ S. Kieniewicz, Prawda margrabiego, „Tygodnik Powszechny” 1946, R. II, nr 32 (73), s. 3-4.

${ }^{22}$ dezet, Rocznica nieprzemyślanego czynu, „Słowo Powszechne” 1949, R. III, nr 22 (656), s. 2.

${ }^{23}$ K. Studentowicz, Sens powstania warszawskiego, „Tygodnik Warszawski” 1948, R. IV, nr 31-32 (140-141), s. 2.

${ }^{24}$ P. Jasienica, Sprawy września, „Tygodnik Powszechny” 1947, R. III, nr 3 (96), s. 3.

25 S. Jasiński, Na marginesie powstań polskich, „Dziś i Jutro” 1946, R. II, nr 43 (49), s. 4. 
polski trafnie nawet oceniał sytuację międzynarodową, zupełnie nie rozumiał jednak Polaków. Ugodowy wobec Rosji, był bezkompromisowy wobec narodu. Taka też była polska tradycja realizmu politycznego - anachronicznego, niepotrafiącego dostrzec problemów społecznych i narodowych, konstatował Zaniec ${ }^{26}$. Publikacja takiej refleksji na łamach „Dziś i Jutro” wpisywała się w zapoczątkowany opublikowanym w 1948 r. Listem otwartym do Pana Juliusza Łady zwrotem w kierunku afirmacji narracji marksistowskich, który miał podłoże zarówno ideologiczne, jak i pragmatyczne wobec totalizacji życia publicznego i kulturalnego ${ }^{27}$. Narracja romantyczna korespondowała $z$ refleksja „Tygodnika Warszawskiego"28, w którym Irena Pannenkowa twierdziła, że powstania, jako wynikające z niezgody na niewolę, były czynem moralnie wartościowym, sprzyjając umocnieniu ducha narodowego. Publicystka polemizowała też $z$ tezą o tym, że każda kolejna insurekcja skazana była na przegraną. „Powstanie Dąbrowskiego”, czyli zryw w zaborze pruskim w 1806 r., był zwycięski, podobnie jak lokalne insurekcje u progu II Rzeczypospolitej. Twierdziła też, że i barżanie, i Kościuszko, i powstańcy listopadowi mogli wygrać. Nawet tragiczne i przegrane powstania styczniowe i warszawskie wzmocniły spoistość narodu, przyciagajac do jego idei warstwy ludowe. Pannenkowa dowodziła, że naród rodził się także $z$ klęsk, ucząc się na błędach. Czy jednak refleksje takie jak jej, w których krytykowała „nadmierny pesymizm", sprzyjały temu ostatniemu ${ }^{29}$ ?

\section{Rzeczpospolita i druga wojna światowa}

Wspomniana publicystka, krytycznie wszak nastawiona do piłsudczyków (była autorką głośnego pamfletu Legenda Piłsudskiego ${ }^{30}$ ), w kontekście oceny polskiej międzywojennej dyplomacji polemizowała $z$ założeniem, że wrogów należy szukać blisko, a przyjaciół

${ }^{26}$ T. Zaniec, Geneza „realizmu” politycznego w Polsce, „Dziś i Jutro” 1954, R. X, nr 4 (426), s. 3; ide m, Geneza „realizmu” politycznego w Polsce. Mit o Aleksandrze Wielopolskim, „Dziś i Jutro” 1954, R. X, nr 9 (431), s. 3; id e m, Mit o Aleksandrze Wielopolskim (III), „Dziś i Jutro” 1954, R. X, nr 10 (432), s. 2-3.

${ }^{27}$ K. Lubieński, List otwarty do Pana Juliusza Lady (Na marginesie notatki $w$ „The Tablet”), „Dziś i Jutro” 1949, R. IV, nr 49 (158), s. 1-2.

${ }^{28}$ O piśmie tym i jego myśli politycznej por. T. Sikorski, M. Kulesza, Niezłomni w epoce fałszywych proroków. Środowisko "Tygodnika Warszawskiego" (1945-1948), Warszawa 2013, passim.

${ }^{29}$ I. Pan nenkowa, Czy nie za wiele pesymizmu?, „Tygodnik Warszawski” 1946, R. II, nr 35 (42), s. 2-3.

${ }^{30}$ J. Lipecki [I. Pannenkowa], Legenda Piłsudskiego, Poznań 1922. 
daleko. Uważała, że naturalnym sojusznikiem Polski sa państwa odległe, niemające $z$ nią sprzecznych interesów, a bezcennym kapitałem międzynarodowym każdego państwa jest szacunek, jakim się ono cieszy i fakt, że jest ono uznawane za potrzebne na arenie międzynarodowej. Tak też nurt romantyczny pojmował polski wysiłek w latach drugiej wojny światowej. Koncepcja ta była jednak uznana przez innych publicystów za co najmniej kontrowersyjna ${ }^{31}$.

Piszac o kampanii 1939 r., Paweł Jasienica, wyjątkowo aktywnie w tym czasie zajmujacy się historia najnowszą ${ }^{32}$, podkreślał bohaterstwo żołnierzy mimo słabości armii, dowodząc, że Polska broniła się dłużej niż mityczne „17 dni”. Przede wszystkim jednak polemizował $z$ teza, że Polskę i Europę uratowałby sojusz polsko-sowiecki. Dowodził, że nie był on de facto możliwy do zawarcia przez ówczesny polski rząd, a Armia Czerwona była o wiele słabsza w 1939 niż w 1941 r. Rozwiązanie, które wybrał pułkownik Józef Beck, było zdaniem publicysty optymalne. W przeciwnym razie, podporządkowania się Niemcom bez wojny, Polska byłaby w wojnie strona przegrana. Wniosek publicysty był wysoce pesymistyczny: do wojny można było się lepiej przygotować, także dyplomatycznie, ale klęska i okupacja były w 1939 r. nieuniknione. Co więcej, to gotowość Polski do oporu sprawiła, że Niemcy nie weszły do wojny w optymalnym dla siebie momencie i żałować tylko należy, że Francuzi nie podjęli polskiej koncepcji wojny prewencyjnej, co do której istnienia publicysta był przekonany (zaznaczał też, że do urealnienia sojuszu $z$ Francja i zawarcia $z$ Wielka Brytanią doszło także dzięki groźbie porozumienia polsko-niemieckiego). Propagowana zatem w innych jego tekstach oszczędność krwi nie oznaczała, że Jasienica był zwolennikiem ugody. Starał się znaleźć wyważone stanowisko między skrajnym realizmem a romantyzmem, twierdzac, że pewna ofiara jest niezbędna do wzmocnienia pozycji kraju na arenie międzynarodowej. Tak też obrona Warszawy w 1939 r. i polski opór we wrześniu zadały Niemcom spore straty, utrudniając im realizację ich planów. Nie mogły być te działania porównywane do powstania warszawskiego, wówczas bowiem brała w nich udział regularna armia, nie zaś „miejska partyzantka”. Zdaniem publicysty opór wojska podtrzymywał też ducha, skłonnej do załamania $z$ powodu klęski, ludności cywilnej ${ }^{33}$. Do tez tych nawiązy-

${ }^{31}$ I. Pannenkowa, Czy nie za wiele..., s. 2.

32 A. Kierys, Polska Jasienicy. Biografia publicysty, Kraków 2015, passim.

${ }^{33}$ P. Jasienica, Od strony frontu i polityki, "Tygodnik Powszechny” 1946, R. II, nr 47 (88), s. 1, 3; ide m, Sprawy września..., s. 3-4; ide m, Wojny, których 
wał Marian Władysław Lis, twierdząc, że przyjęcie przez wszystkich przeciwników Adolfa Hitlera wariantu czeskiego oznaczałoby bezkrwawe zwycięstwo Niemców ${ }^{34}$. Podobnie rzecz ujmował Bocheński, podnosząc heroizm żołnierzy, i dowodząc, że przed Polska stała alternatywa kapitulacji albo walki skazanej na klęskę. Znamienne, że nawet on uznawał, że szkody, jakie wynikłyby $z$ ugody $z$ Niemcami byłyby większe niż z przegranej wojny. Twierdził tak w przededniu samego konfliktu, jednakże nieco wcześniej jeszcze wzywał do unormowania stosunków polsko-niemieckich w duchu wzajemnych ustępstw. Z zaborczym hitleryzmem, twierdził Bocheński, jednak od 1939 r. po lata czterdzieste II Rzeczpospolita pertraktować nie mogła ${ }^{35}$. Michał Straszewski zwracał jednak uwage na to, że Beck w 1939 r. nie miał możliwości manewru $z$ własnej winy - stracił ją jego zdaniem w 1938 r., godząc się na wyeliminowania z gry Czechosłowacji ${ }^{36}$.

Postawa Polaków w latach wojny to skutek kompleksów czasów zaborów, przekonania, że im więcej krwi polskiej zostanie przelanej, tym większa będzie przyszła odrodzona Rzeczpospolita - dowodził Przetakiewicz. Przeciwstawienie honoru narodowego zasadom racji stanu przez Polaków musiało być cynicznie wykorzystane przez obcych. W wypadku wojny okazali się nimi Anglicy, wykorzystując polski romantyzm ${ }^{37}$. Dlatego też, przekonywał

nie było, „Tygodnik Powszechny” 1947, R. III, nr 13 (106), s. 1, 3; idem, Relacje dwóch ambasadorów, „Tygodnik Powszechny” 1947, R. III, nr 14-15, s. 3-4; id e m, Mimo wszystko, „Tygodnik Powszechny” 1947, R. III, nr 6 (99), s. 4; id e m, Od izolacji do wspólnoty, „Tygodnik Powszechny” 1947, R. III, nr 24 (117), s. 6; id e m, Wrzesień i sierpień, „Tygodnik Powszechny” 1949, R. V, nr 19 (217), s. 1. Por. J. Kirchmayer, Rozmowa z Pawłem Jasienica, „Tygodnik Powszechny” 1947, R. III, nr 6 (99), s. 3-4; W. Brus, Wojny, których nie było i których nie planowano, „Tygodnik Powszechny” 1947, R. III, nr 24 (117), s. 4-6.

${ }^{34}$ M.W. Lis, O realizmie i polityce, "Tygodnik Powszechny” 1947, R. III, nr 7 (100), s. 7-8.

${ }^{35}$ A. Bocheńs ki, O dyskusji..., s. 1, 4; i de m, „Amocklauf”, „Polityka” 1939, R. X, nr 15 (189), s. 1; id e m, List do narodowców, „Bunt Młodych” 1935, R. VI, nr 12-13 (79-80), s. 1. Por. T. Cy prian, J. S aw i cki, Polityka zagraniczna dwudziestolecia, „Tygodnik Powszechny” 1946, R. II, nr 49 (90), s. 7. Pertraktować jednak powinni Polacy w latach okupacji, chroniąc się w ten sposób od represji, dowodził Bocheński, zmierzając wówczas do utworzenia proniemieckiej polskiej administracji w Generalnym Gubernatorstwie. A. Orzełek, Poszukiwanie modelu realizmu politycznego. Myśl i publicystyka Aleksandra Bocheńskiego, Lublin 2019, s. 160-179.

${ }^{36}$ M. Stra s zew s ki, Błędy polityki przedwrześniowej, „Tygodnik Powszechny” 1946, R. II, nr 49 (90), s. 7.

${ }^{37}$ Z. Przetakiewicz, Nakaz realizmu. „Krwia polska dowiedźmy światu nasze prawo do niepodległości”, „Dziś i Jutro” 1947, R. III, nr 4 (61), s. 1. 
Jasienica, największe znaczenie miała ofiara złożona na ojczystej ziemi, a nie poza jej granicami ${ }^{38}$.

Dominik Horodyński, oficer Armii Krajowej (dalej: AK), upominał się o szacunek dla jej żołnierzy. Nie przeczył zarzutom, że służyli oni złej koncepcji politycznej, wynikało to jednak $z$ ich karności i posłuszeństwa powiazanych $z$ patriotyzmem. Zaznaczał też, że nie zawsze AK „stała $z$ bronią u nogi”, ale podjęła szereg akcji czynnych przeciwko Niemcom na długo przez wkroczeniem Sowietów ${ }^{39}$. Jasienica, także oficer AK, pisał wprost, że taktyka minimalizowania strat była słuszna wobec i tak wielkiego upustu krwi polskiej ${ }^{40}$, ale i podkreślał wielką solidarność narodową wobec okupantów ${ }^{41}$. W kontekście działań wojsk polskich na Zachodzie wypowiedział się Bocheński, krytykując szafowanie krwią polską przez przywódców, ale jednocześnie w absorbującej wówczas polska publicystykę kwestii Monte Cassino dowodząc, że żołnierze rozkaz Andersa wykonać musieli ${ }^{42}$.

Należy mieć na uwadze to, że problem oceny polskiej polityki zagranicznej w latach 1939-1944 był kluczowy dla „polityki historycznej" komunistów, często posługujących się argumentem o zupełnym skompromitowaniu sanacji i "obozu londyńskiego" w latach drugiej wojny światowej, co prowadziło do dezawuowaniu tradycji II Rzeczypospolitej w ogóle. Publicyści katoliccy dotykający tej tematyki ryzykowali zatem wpisaniem się w schemat urzędowej propagandy.

\section{Powstanie warszawskie}

Zasadnicze znaczenie dla powojennych sporów o realizm i romantyzm miała kwestia powstania warszawskiego ${ }^{43}$. Znamienne, że w pierwszych latach powojennych na łamach prasy środowisk katolickich nie istniało ścisłe rozgraniczenie na grupe Piaseckiego

${ }^{38}$ P. Jasienica, Dziesięciolecie, „Tygodnik Powszechny” 1949, R. V, nr 35 (233), s. 5.

${ }^{39}$ D. Horodyń ski, O tradycje żołnierska A.K., „Dziś i Jutro” 1945, R. I, nr 4, s. $3-4$.

${ }^{40}$ P. J a sienica, „Z bronia u nogi”, „Tygodnik Powszechny” 1946, R. II, nr 37 (78), s. 3-4.

${ }^{41}$ I d e m, Warto pogadać, „Tygodnik Powszechny” 1947, R. III, nr 9 (102), s. 4-5.

${ }^{42}$ A. Bocheński, O dyskusji..., s. 5.

43 Spór o powstanie warszawskie $w$ powojennej publicystyce polskiej 19451981, red. D. Gawin, Warszawa 2004. 
i „Tygodnika Powszechnego”. Publicyści związani z tymi nurtami często gościli na łamach „konkurencyjnego” pisma. Tak też, poruszając problematykę zrywu stolicy, Wojciech Kętrzyński, adiutant Bolesława Piaseckiego, początkowo jawił się jako zwolennik decyzji Komendy Głównej AK. Sprzeciwiał się upraszczaniu zagadnienia do rozbieżności między bohaterstwem warszawiaków a błędami dowództwa. Starał się dowieść, że u podstaw insurekcji legła przede wszystkim sponiewierana przez Niemców narodowa godność, która w warszawiakach wytworzyła przekonanie, że powstanie musi wybuchnać. Na to gotowali się przez pięć lat okupacji i innego scenariusza niż zemsta na znienawidzonych okupantach sobie nie wyobrażali. Jeśli zatem powstanie było „nieodwracalną koniecznością", jeśli żołnierze mimo świadomości klęski trwali na barykadach, to Warszawy nie dało się uratować. Ewakuacja ludności przez Niemców skończyć by się mogła jej masakrą, a walki niemiecko-sowieckie nie dość, że zniszczyłyby miasto, mogłyby sprowokować niekontrolowana insurekcję. Kętrzyński twierdził zatem, że Polacy świadomie poszli w bój skazany na klęskę. Wobec tego oczywiście łagodna musiała być ocena decydentów, mimo ich błędnej koncepcji politycznej. Jak wspomniałem, już w roku 1946 Kętrzyński pisał o powstaniu w zupełnie inny sposób, twierdząc m.in., że było ono tragiczną konsekwencją niepopularności wśród Polaków koncepcji realistycznych ${ }^{44}$.

$Z$ tezą o nieuchronności powstania nie zgadzał się inny oficer podziemia, Dominik Horodyński. Dowodził, że jedynie żołnierze AK posiadali w Warszawie broń, więc tylko oni byli zdolni do wywołania powstania, nigdy jednak nie zrobiliby tego bez rozkazu, byli wszak wojskiem karnym i zdyscyplinowanym. Krytykował dowództwo, które rzuciło tych ideowych ludzi do skazanej na klęskę walki, unikał jednak początkowo oceny politycznych aspektów decyzji ${ }^{45}$. W miarę rozwoju sytuacji politycznej zmieniał też swoje oceny. Już w 1948 r. pisał o „zbrodni lekkomyślności politycznej i wojskowej" decydentów, którą to opinię podzielać miał ogół narodu ${ }^{46}$.

${ }^{44}$ W. Kętrzyński, Warszawa 1944, „Tygodnik Powszechny” 1945, R. I, nr 21, s. 1; idem, Problem Wielopolskich..., s. 2-3; idem, Historyczne perspektywy, „Tygodnik Powszechny” 1945, R. I, nr 28, s. 2.

${ }_{45}$ D. Horodyński, W tragiczna rocznice, „Dziś i Jutro” 1946, R. II, nr 20 (36), s. 2-3.

${ }^{46}$ I d e m, Dzień Żałoby, „Dziś i Jutro” 1948, R. IV, nr 31 (140), s. 1. 
W 1952 r. z kolei decydenci była to "garstka głupich i bez sumienia przywódców londyńsko-delegackich" 47 . Jan Dobraczyński jako date przełomowa w historii Warszawy i Polski wskazywał jej zajęcie przez wojska sowieckie i polskie 17 stycznia $1945 \mathrm{r}^{48}$ Oficjalnie „Dziś i Jutro” uznawała decyzję o rozpoczęciu walki w Warszawie za dowód politycznej i wojskowej nieodpowiedzialności, przejawiającej się w nieuzgodnieniu współdziałania z Armią Czerwoną. Równocześnie jednak doceniano bohaterstwo powstańców i podziemia, domagając się pomnika dla pokolenia, którego udziałem stał się „wielki mit heroiczny”, u którego podstaw legła jednak zbrodnia politycznej nieodpowiedzialności ${ }^{49}$. Podobnie sprawę ujmował Andrzej Micewski: podnosząc heroizm powstańców, zaznaczał zupełny absurd koncepcji politycznej powstania - było ono wymierzone politycznie w Sowietów, a nie mogło wygrać bez ich pomocy. Twierdził przy tym, że Armia Czerwona nie mogła pomóc Warszawie, gdyż w swych działaniach jej dowództwo kierowało się ogólnymi celami wojny, a nie dążeniem do pomocy antysowieckiej inicjatywy politycznej. Powstanie było jego zdaniem wykorzystaniem bohaterstwa młodzieży przez przedstawicieli przegrywajacych koncepcji politycznych, chcących w ten sposób ostatni raz zawalczyć o władzę ${ }^{50}$.

Stefan Żurowski wysuwał tezę o brytyjskiej inspiracji. Anglicy, według publicysty, prowokując powstanie, chcieli wzmocnić swego protegowanego, Stanisława Mikołajczyka, w sporze z Józefem Stalinem $^{51}$. Nurt krytyczny wobec powstania reprezentował też Jasienica, przekonując, że Warszawa nie była skazana na zagładę ze względów wojskowych ani $z$ powodu rzekomego braku dyscypliny żołnierzy AK. Zryw był politycznym i wojskowym absurdem, nie mogąc uzyskać pomocy Sowietów. Polityków i dowódców pociagały jednak sława Monte Cassino, obawa przed przydaniem im miana "defetystów”, typowe dla Polaków mierzenie sił na zamiary i zupełne lekceważenie strat ludności cywilnej. „Jakżeby inaczej wyglądało dziś życie w Polsce - pisał Jasienica - gdyby nie warszawskie

47 Id e m, Płodny pył tamtych dni (impresje rocznicowe), „Dziś i Jutro” 1952, R. VII, nr 36 (354), s. 1.

48 J. Dobraczyński, W czwarta rocznice, „Słowo Powszechne” 1949, R. III, nr 16 (650), s. 1.

491 sierpnia, „Dziś i Jutro” 1949, R. V, nr 30 (182), s. 1.

50 A. Micewski, 2-X-1944, „Słowo Powszechne” 1951, R. V, nr 260 (1602), s. 3-4.

${ }^{51}$ S. Żu row ski, Myśli o powstaniu, „Dziś i Jutro” 1950, R. VI, nr 31 (245), s. 1. 
cmentarzysko. Nie ma takiej dziedziny życia narodowego, która by tego ciężaru nie czuła". Był to skutek skrajnego deficytu realizmu politycznego w Polsce ${ }^{52}$. Najkrytyczniejszy był wobec decyzji o rozpoczęciu walki w Warszawie Bocheński, pisząc, że: „tylko wielkość skutków, jakie błąd przyniósł - utrata stolicy, przewyższyła kolosalność jego teoretycznej nonsensowności”. Zdyscyplinowani żołnierze AK nie wywołaliby walki samorzutnie, dowodził Bocheński, ale wykonali rozkaz, ginąc i dowodząc, że „kierownictwo narodowe może zawsze liczyć na maksymalny wysiłek, gdy uzna, że zaszła tego potrzeba”, toteż „winniśmy im za tę determinację wieczną wdzięczność i uwielbienie" $"$ s3.

O wiele bardziej wyważona, daleka od skrajności, była krytyka powstania warszawskiego rozwinięta na łamach „Tygodnika Powszechnego” i „Tygodnika Warszawskiego” przez Stefana Kisielewskiego. Było ono klęską, do której Polska nieuchronnie zmierzała, nie mogło to jednak usprawiedliwić decydentów i nie powinni oni tłumaczyć się rzekoma groźbą samorzutnego wybuchu walk, pisał słynny felietonista. Polacy nie mieli psychiki adekwatnej do warunków geopolitycznych, w których przyszło im żyć. Polska, położona między dwoma wielkimi mocarstwami, nigdy mocarstwem być nie mogła, winna być zatem sprytnym, „obrotowym” pośrednikiem. Tymczasem Polacy byli bezkompromisowi, konfliktując się $z$ większością sąsiednich nacji. Wzbudzało to poczucie niezawinionej krzywdy, rodząc mesjanizm, wzmacniając irracjonalne tendencje. Maksymalistyczny patriotyzm uniemożliwiał realne spojrzenie na świat, za zdradę uznając nie tylko ugodę, lecz także taktyczne ustępstwo. Żarliwość wypalała fizycznie naród aż po powstanie warszawskie. Realiści polscy jednak nie potrafili przekonać do swych racji rodaków. Idąc w poprzek oczekiwań narodu, stawali się pseudorealistami, wyzutymi ze społeczności patriotów. Tak też romantycy stawali się realistami względem narodu, wiodąc go ku kolejnym klęskom. Taka była tragiczna historiozofia dziejów Polski, która przełamać powinno zarówno zwalczanie nurtów romantycznych, jak i zrozumienie potrzeby „sojuszu” polsko-sowieckiego ${ }^{54}$.

${ }^{52}$ P. Jasienica, Wrzesień i sierpień..., s. 2-3.

53 A. Bocheński, O dyskusji..., s. 5.

${ }^{54} \mathrm{~S}$. Kis ielews ki, O odwiecznym konflikcie polskim (w II rocznice powstania warszawskiego), „Tygodnik Warszawski” 1946, R. II, nr 31 (38), s. 1; id e m, Porachunki narodowe (artykuł dyskusyjny), „Tygodnik Powszechny” 1945, R. I, nr 24, s. 2. 
W innym bowiem przypadku, dopowiedzieć można za Kisielewskiego, piszacego wszak w sytuacji ciagle politycznie niejasnej, ci, którzy wyznaja u progu okresu powojennego koncepcje ugodowe, znowu rozminą się $z$ oczekiwaniami swych rodaków, co doprowadzi do katastrofalnych skutków. Inny publicysta „Tygodnika Warszawskiego", Marian W. Lis rozpatrywał powstanie warszawskie przede wszystkim przez pryzmat niebywałego heroizmu walczących i solidarności narodowej, której odbiciem była zupełna demokratyzacja stosunków w walczącej stolicy. Powstanie dowodziło, że w każdym człowieku tkwi zdolność do wielkości i była to prawda humanistyczna i chrześcijańska, której pominąć nie mogła najbardziej nawet krytyczna ocena decyzji o rozpoczęciu walki ${ }^{55}$. Jerzy Braun, będący jednym $z$ najważniejszych publicystów pisma, argumentował, że powstanie warszawskie było najpełniejszym wyrazem heroicznego ducha epoki, a Studentowicz, mimo że krytykował wcześniejsze insurekcje, uznawał, że powstanie miało szanse na zwycięstwo i warto było podjać ryzyko jego rozpoczęcia ${ }^{56}$.

Najgłębsza jednak refleksję nad powstaniem warszawskim podjął Antoni Gołubiew. Pisał on w "Tygodniku Powszechnym”, że spór o tę insurekcję to nie tylko kwestia oceny męstwa powstańców i decyzji politycznych, które do niego wiodły, lecz także spór o drogę, którą winien podażać naród. Autor Bolesława Chrobrego wchodził wbrew swej woli w kwestię rozsądzenia tych, którzy twierdzą, że niewywołanie powstania dowodziłoby załamania się narodu, i tych, których zdaniem reagowanie zrywem w każdej sytuacji, bez liczenia się ze stratami, jest dowodem braku wyrobienia politycznego. Chciał przede wszystkim powstanie traktować jako czyn bojowy, a nie demonstracje, bo i nie wolno narodowi uprawiać demonstracji takim kosztem - kosztem wielkiego miasta, jego ludności, infrastruktury i dorobku kulturalnego. A jako czyn bojowy insurekcja była błędem o tragicznych skutkach, w którym straty znacząco przewyższyły zyski. Została po nim legenda, pamięć bohaterstwa, ale i bez nich, zdaniem publicysty, naród nie załamałby się moralnie. Fakt, że Warszawa solidarnie walczyła, nie oznaczał bowiem, że solidarnie do powstania parła. Dowiodła jednak, że Polacy potrafia bić się „solidarnie i irracjonalnie bohater-

55 M.W. Lis, Powstanie Warszawskie, „Tygodnik Warszawski” 1947, R. III, nr 31, s. 1 .

${ }^{56}$ J. Braun, Czasy ekstatyczne, „Tygodnik Warszawski” 1948, R. IV, nr 31-32 (140-141), s. 1, 4; K. Studentowicz, op. cit., s. 2. 
sko", co leżeć miało głęboko w psychice narodu. I chociaż postawa ta nie powinna kierować polityka polska, to jej istnienia nie mogli lekceważyć decydenci, którzy winni być realistami także względem uczuć narodu, które należało kształtować, ale nigdy lekceważyć ${ }^{57}$.

\section{Współczesne konsekwencje}

Charakteryzowane narracje służyły zarówno refleksji nad przeszłością, jak i wyciagnięciu $z$ niej wniosków na teraźniejszość i przyszłość. Realizm polityczny, dowodził Kętrzyński w kontekście Wielopolskiego, musiał opierać się nie tylko na znajomości sił swoich i obcych, lecz także na zrozumieniu społeczeństwa. Tego zaś wielu polskim realistom brakowało. Był to „realizm względem narodu", jego zaś deficyt u ludzi, potrafiących rozumnie pojmować politykę, był przyczyną ich klęski w starciu $z$ romantykami. Być może, sugerował Kętrzyński, Margrabia wyraził to w swych słynnych słowach o Polakach, dla których „można czasem coś zrobić”, ale $z$ którymi coś osiagnąć nie sposób. Gdzie zaś Polacy mieli się nauczyć kultury politycznej, w czasach, gdy własne instytucje życia politycznego zastępowała im literatura romantyczna? Jeśli ich duma narodowa była poniewierana, podejrzliwie spoglądali na każdego, kto chciał ugody z zaborca. Stąd wynikał jednostronny kult insurekcji i jednostronne potępienie realizmu ${ }^{58}$. Ze sporu zaś nurtu romantycznego i heroicznego, nurtu bezgranicznej ofiary i nurtu rozumnej, ale i giętkiej ugody, nie wynikało w polskiej historii nic dobrego. Historia realistów bowiem to historia „zamiarów bez skutków, myśli słusznych i realnych, głębokich koncepcyj politycznych, społecznych, gospodarczych, lecz nie zrealizowanych, gdyż walka ich kończyła się niemal zawsze gorzkimi rozdźwiękami $z$ własnem społeczeństwem” i dlatego też historia Polski była historia „czynów bez zamiarów i zamiarów bez skutków”59. Identycznie w zasadzie rzecz ujmował Kisielewski, widząc w tym tragizm polskich dziejów i polityki polskiej. Konsekwencją był postulat rzetelnej pracy nad podniesieniem politycznego poziomu zbiorowości, tak aby Polska „Z wielkiej idei” stała się „wielką siłą w świecie realiów”60.

57 A. Gołubiew, Myśli o powstaniu warszawskim, „Tygodnik Powszechny” 1946, R. II, nr 31 (72), s. 1-2.

${ }^{58}$ W. Kętrzyńs ki, Problem Wielopolskich..., s. 2-3.

${ }^{59}$ I d e m, Historyczne perspektywy..., s. 1-2.

60 S. Kisielewski, O odwiecznym konflikcie..., s. 1. Sprzeciwiał się jednak wulgarnemu i schematycznemu ujmowaniu pokolenia AK jako reakcjonistów. I d e m, Przeciw „dwóm frontom”, „Tygodnik Warszawski” 1946, R. II, nr 11 (18), s. 3. 
Jasienica bardzo ostro przestrzegał w „Tygodniku Powszechnym” w 1946 r. przed nowymi próbami konspiracji. Wyniszczają one jedynie naród, jego siły, zwłaszcza wśród młodych, a opierają się na błędnym przekonaniu, że kto więcej krwi przeleje, mniej będzie liczył się za stratami materialnymi, ten zdobędzie większe uznanie w świecie i będzie zwycięzcą w konflikcie narodów i państw ${ }^{61}$. Jerzy Zagórski zaś krytykował szczególnie w Polsce rozpowszechnione przekonanie o konieczności „rzucania kamieni na szaniec”, czyli wystawiania do walki nieuzbrojonej patriotycznej młodzieży ${ }^{62}$.

Przetakiewicz jeszcze skrajniej przedstawiał konsekwencje odrzucenia realizmu politycznego. Jeśli bowiem dotychczasowe kompleksy „naród nasz ku przepaści pchaja, które $z$ nas, narodu o wielkiej przeszłości i możliwościach, czynią narzędzie cudzej rozgrywki a nam pozostawiaja ruiny miast i krzyże grobów powstańczych", to „naród, który przekroczy dopuszczalne granice upływu krwi, obumiera. Jesteśmy nad granica przepaści"63. Tymczasem, dowodził zastępca Piaseckiego, „obecna konspiracja”, tak jak gen. Władysław Anders czy gen. Stanisław Maczek działała w interesie Anglików, co prawda nieświadomie. Ci Polskę traktowali i traktuja jako czynnik osłabiajacy Rosję. Najwyższa pora, dowodził, aby faktycznie Polacy zaczęli myśleć o własnych interesach ${ }^{64}$. Dobraczyński z kolei, oddając hołd bohaterstwu pokoleniu podziemia, nie tylko zastanawiał się nad sensownościa niektórych brawurowych akcji, lecz także podkreślał, że pokojowe czasy wymagają nie heroizmu wojennego, ale codziennej, systematycznej pracy dla zbiorowości ${ }^{65}$.

Wszystko to jednak nie oznaczało odrzucenia tradycyjnie rozumianych honoru i moralności w polityce, pisał Jasienica, sprzeciwiajac się wulgarnemu utylitaryzmowi społecznemu marksistów ${ }^{66}$. Tradycja żołnierska AK to tradycja apolityczna, patriotyczna i moralnie wielka, twierdził Horodyński. Tragizm żołnierzy Armii Krajowej, którzy u schyłku wojny, mimo swego męstwa i poświęce-

${ }^{61}$ P. J a si enica, Nie wolno, „Tygodnik Powszechny” 1946, R. II, nr 50 (91), s. 2.

62 J. Zagó rs ki, Przywara narodowa nr 1, „Tygodnik Powszechny” 1946, R. II, nr 11 (52), s. 1 .

${ }^{63}$ Z. Przetakiewicz, Nakaz realizmu..., s. 1.

${ }^{64}$ Ibidem.

65 J. Dobraczyński, Hierarchia bohaterstwa, „Słowo Powszechne” 1949, R. III, nr 121 (756), s. 1 .

${ }^{66}$ P. J a sienica, Honor, „Tygodnik Powszechny” 1946, R. II, nr 13 (54), s. 3. 
nia, zastali Polskę inną niż ta, o której mówili ich dowódcy, zasługuje na szacunek i winien stać się podstawa pojednania i braterstwa wszystkich obozów wywodzących się $z$ konspiracji ${ }^{67}$. Czy jednak dążeniem do jedności były sformułowania z $1953 \mathrm{r}$. tego samego autora, stawiajace w jednym rzędzie oficerów Komendy Głównej AK i „odrodzony Wehrmacht”68?

W dziedzinie relacji międzynarodowych zasadnicza konsekwencją przyjęta $z$ przebiegu wojny była dla „Dziś i Jutro” potrzeba utrzymania przyjaznych relacji ze Związkiem Sowieckim, państwem, które zdołało położyć kres niemieckiej okupacji Polski ${ }^{69}$. Brakowało $\mathrm{w}$ tej refleksji jednak tego, o czym pisal Jasienica - pamięci o wyciagnięciu wniosków z przeszłości: nienarzucania sojuszu siłą ${ }^{70}$. "Określenie realistyczne zawsze będzie stanowić najwyższą pochwałę dla prawdziwie wielkiej, skutecznej linii politycznej”, pisano w 1947 r. w „Dziś i Jutro”, wskazując na konieczność zerwania $z$ tendencjami romantycznymi i emocjonalnymi w ocenia zjawisk politycznych. Analizując jednak narracje historyczne w prasie Piaseckiego, zauważyć można, obok skłonności do realizmu, skłonność do wybielania za wszelką cenę wschodniego sąsiada i - utrzymane w wyjątkowo schematycznym propagandowym stylu - nawoływania do wyciągnięcia wniosków $z$ przeszłości $\mathrm{w}$ postaci pełnego zaangażowania się po stronie obozu władzy ${ }^{71}$.

Inaczej rzecz ujmował Jan Piwowarczyk w „Tygodniku Powszechnym", argumentując, że pojęcie racji stanu powinno nabrać wymiaru etycznego, nierozerwalnie $z$ nim się łącząc, nie zaś zakładając prymat polityki nad moralnością ${ }^{72}$. „Tygodnik Warszawski” głoszący chrześcijański radykalizm społeczny był w dziedzinie politycznej przepojony optymistycznym mesjanizmem. Sprawa polska była sprawa humanitarnych ambicji ludzkości, nierozerwalnie związanych $\mathrm{z}$ chrystianizmem. Wysoka etyka w polityce międzynarodowej była niezbędna i to ona w ostateczności miała zwyciężyć. Konsekwencja miało być też zwycięstwo koncepcji państwa

67 D. Horodyńs ki, Dzień Żałoby..., s. 1.

${ }^{68}$ I d e m, Po dziewięciu latach, „Dziś i Jutro” 1953, R. IX, nr 31 (401), s. 1.

69 Przyjaźń, „Słowo Powszechne” 1950, R. IV, nr 108 (1095), s. 1.

${ }^{70}$ P. Jasienica, Z pradem historii, „Tygodnik Powszechny” 1946, R. II, nr 18 (59), s. 2.

71 Realizm, „Dziś i Jutro” 1947, R. III, nr 30 (87), s. 1.

72 J. Piw ow a rczyk, „Racja stanu”, „Tygodnik Powszechny” 1947, R. III, nr 38 (131), s. 1. 
chrześcijańskiego. Realizm był w tej optyce anachroniczny, a rzekomo utopijny idealizm nowoczesny ${ }^{73}$. Publicystyka "Tygodnika” odrzucała go także jako $\mathrm{w}$ istocie nihilistyczny, niepotrafiący sprostać wyzwaniom epoki „wielkich idei” i zrozumieć aspiracji społeczeństwa ${ }^{74}$. Nawet Dobraczyński, który wkrótce związał się $z$ Piaseckim, piszac o tym, że Polacy są wielcy w czasach nieszczęść, ale mało systematyczni i solidni w czasie pokoju, nie deprecjonował jeszcze w pierwszym numerze pisma tradycji powstańczej ${ }^{75}$.

Stąd też odpowiedź Ireny Pannenkowej na tezy Bocheńskiego, głosząca potrzebę syntezy realizmu i bohaterstwa, nieodzowną w tej części Europy. Bohaterstwo nie na rozkaz, ale wynikające $z$ głębokich przekonań narodu było zawsze wartością dodaną i taka, która należało promować, a nie zwalczać, także w „dobie bomby atomowej”, czyli wojen totalnych. Był to jej zdaniem większy realizm niż apologia ugody, bo liczący się zarówno $z$ uczuciami narodowymi, jak i z czynnikami międzynarodowymi, które rzekomo jej zdaniem, realiści lekceważyli. Pannenkowa twierdziła, że Bocheński i Pruszyński nadto dowierzali zaborcy, dostrzegali jego dobra wolę tam, gdzie jej nie było, złośliwie zauważajacc, że przed wojna, jako „mocarstwowcy”, głosili zupełnie inne pogladdy ${ }^{76}$. Bliska temu była refleksja Jasienicy nad Dziejami głupoty... Bocheńskiego. Publicysta twierdził, że ujmowanie realizmu przez autora Pamfletów dziejopisarskich było anachroniczne, bo lekceważące istotną jego zdaniem po wojnie kwestię moralności w relacjach międzynarodowych. Historia nie była tylko dziejami decydentów, twierdził, lecz także wpływających na nie emocji mas, o których Bocheński zapominał ${ }^{77}$.

On sam w swoich artykułach w „Tygodniku Powszechnym” twierdził, że naród, który nie jest skłonny do bohaterstwa, skazany jest na klęskę. Rzecz w tym, dowodził publicysta, aby za ofiar-

${ }^{73}$ J. Braun, Polski ideał państwa chrześcijańskiego. W rocznicę Konstytucji 3 Maja, „Tygodnik Warszawski” 1947, R. III, nr 18, s. 1-2.

${ }^{74}$ Żu r, O nierealnym realiźmie, "Tygodnik Warszawski” 1948, R. IV, nr 10 (119), s. 7.

${ }^{75}$ J. Dobraczyński, O charakterze narodowym, „Tygodnik Warszawski” 1945, R. I, nr 1, s. 3.

${ }^{76}$ I. Pannenkowa, Realizm, bohaterstwo $i$ - bomba atomowa, „Tygodnik Warszawski” 1947, R. III, nr 19, s. 3-4; eade m, Realizm romantyków, „Przegląd Powszechny” 1948, R. LXVI, t. 228, s. 226-236; eadem, Mentorzy, „Tygodnik Warszawski" 1947, R. III, nr 49 (108), s. 3-4.

77 P. J a s i enica, Cień Machiawela, „Tygodnik Powszechny” 1947, R. III, nr 31 (124), s. 4-5. 
nością Polaków szedł realizm decydentów, trzeźwe ważenie przez nich sił własnych i obcych, nie zaś wiara w pomoc Zachodu, kierowanie się emocjami czy poczuciem honoru. Żołnierz polski zawsze rozkaz wykona (dowiodła tego historia) i być może nieraz jeszcze będzie musiał wykonać. Niech jednak nie ginie bez wyraźnej korzyści politycznej. Aby ten warunek był spełniony, potrzebna była pozytywistyczna praca intelektualna nad redefinicja polskiej myśli politycznej ${ }^{78}$. $Z$ publicystą zgodził się Michał Lewicki, twierdząc, że pokój nie jest dany raz na zawsze i nie gwarantują go broń atomowa ani Organizacja Narodów Zjednoczonych ${ }^{79}$, żołnierz Września Franciszek Wydra ${ }^{80}$, Konstanty Syrewicz ${ }^{81}$, a także anonimowy uczeń klasy licealnej ${ }^{82}$. Marian Władysław Lis pisał, że o znaczeniu bohaterstwa świadczy to, że dokonał jego pochwały publicysta słynacy $z$ czysto logicznej argumentacji ${ }^{83}$, Paweł Jasienica zaś uznał ujęcie Bocheńskiego za niezwykle trafne ${ }^{84}$. Stanowiska tego nie aprobowała jednak Hanna Malewska, publicystka „Tygodnika Powszechnego", domagając się współcześnie zwalczania kultu heroizmu wojennego, obawiajac się, że pchnie on Polaków do kolejnej konspiracji. W razie faktycznego zagrożenia nie zabrakłoby $z$ pewnościa pokładów ofiarności $w$ narodzie, obecnie jednak potrzebna była „czechizacja” Polaków i przekonanie ich, że chłodna kalkulacja nie jest ohydna moralnie. Bocheński, pisała, prowadzi do rozdwojenia politycznego realizmu, co nie mogło być użyteczne $\mathrm{w}$ narodowym wychowaniu. Jeśli bowiem Polacy w dalszym ciagu dorastać będą w kulcie powstań i nawet w atmosferze krytyki przywódców, to wykonają każdy bezrozumny rozkaz i doprowadzą do kolejnej katastrofy. Doprawdy potężna była siła wojennej traumy w publicystyce polskiej, jeśli autora Dziejów głupoty... uznawano za zgoła romantyka ${ }^{85}$. Podobnie Witold Kirchmayer w zawiłym

${ }_{78}$ A. Bocheński, O dyskusji..., s. 5. Por. E. Kristanova, op. cit., s. 135.

${ }^{79}$ M. Lewicki, Co jest prawda, a co chimera, „Tygodnik Powszechny” 1947, nr 7 (100), R. III, s. 6.

80 F. Wy d r a, Głos żołnierza, „Tygodnik Powszechny” 1947, R. III, nr 7 (100), s. 8.

${ }^{81}$ K. Syrewicz, Problem źle postawiony, „Tygodnik Powszechny” 1946, R. II, nr 49 (90), s. 7.

82 A.S., Spór o ideę, „Tygodnik Powszechny” 1947, R. III, nr 7 (100), s. 8.

${ }^{83}$ M.W. Lis, O realizmie..., s. 7-8.

84 jas. [P. Jasienica], Polityczna waga heroizmu, „Tygodnik Powszechny” 1946, R. II, nr 46 (87), s. 12.

${ }^{85}$ H. Malewska, Realizm?, „Tygodnik Powszechny” 1946, R. II, nr 49 (90), s. 6; e ad e m, Jeszcze o kulcie heroizmu wojennego, „Tygodnik Powszechny” 1947, R. III, nr 10 (103), s. 4. 
wywodzie starał się dowieść, że Bocheński myli obowiązek $z$ bohaterstwem, dając się uwieść tendencjom romantycznym. Lekceważyć miał fakt, że wojskowi, jako decydenci, powinni być jednocześnie realistami i „obowiązkowymi bohaterami”. Wojna bowiem coraz bardziej stawała się, także w kwestii decyzji, sprawą wojskowych, a nie polityków ${ }^{86}$.

Bocheński, kończąc dyskusję na temat tych wątków, dowodził, że żaden naród w powojennym świecie nie chciał się moralnie rozbrajać, gdyż nie można było mieć pewności, że druga wojna światowa była ostatnia wojna ludzkości. Toteż nie wystarczyłyby na okoliczność kolejnego konfliktu same rozkazy, sprawna organizacja, bez skłonności obywateli do poświęcenia. Oczywiście o tym, czy poświęcenie jest celowe, decydować moga tylko politycy, bywaja jednak rozkazy, których wykonanie wymaga bohaterstwa. To zaś, podobnie jak dyscyplina wobec trudnych nawet rozkazów władzy zwierzchniej, wymaga odpowiedniego wychowania narodowego ${ }^{87}$. Kończac refleksję nad ta polemika, zauważyć równocześnie należy, że toczyła się ona w warunkach największego natężenia konfliktu politycznego - między referendum 30 czerwca 1946 r. a wyborami do Sejmu Ustawodawczego. Odczytywać ją zatem można także jako próbę rozważań nad wyborami polskiej inteligencji w sytuacji coraz bardziej prawdopodobnego opanowania całości życia publicznego przez komunistów. Czy traktować ich jako „pozytywistów”, „realistów", czy też jako okupantów, i jakie wnioski z tych konstatacji wyciagnąć? - to pytanie było kluczowe nie tylko dla grup katolickich, ale w ogóle dla definicji sytuacji politycznej w Polsce. Jak się wydaje, nad tym też toczyła się „dyskusja o Monte Cassino”.

\section{Wnioski}

Scharakteryzowane w artykule wypowiedzi umożliwiała względna swoboda dyskusji prasowej w pierwszych latach powojennych. Prowadzone polemiki dowiodły, że niewygasła jest w polskiej myśli politycznej, mimo klęski wojennej, tradycja romantyczna. Co prawda rzadko pojawiały się teksty wprost nawiązujące do rozpo-

${ }^{86}$ W. Kirch mayer, Bohaterstwo i rozdział kompetencji, „Tygodnik Powszechny" 1946, R. II, nr 49 (90), s. 7-8.

87 A. Bocheński, Odpowiadam oponentom, „Tygodnik Powszechny” 1947, R. III, nr 7 (100), s. 6-7. O całej „dyskusji o Monte Cassino” por. A. Orzełek, Poszukiwanie modelu realizmu..., s. 202-206. 
wszechnionych w II Rzeczypospolitej wyobrażeń, jednakże starano się często albo romantyzmu bronić jako wnoszącego istotne wartości do życia narodowego, albo dokonywać jego syntezy $z$ realizmem. Publicyści „Tygodnika Warszawskiego” oraz „Dziś i Jutro” starali się zwykle przedstawić pozytywne strony tradycji romantycznej, istotnej także we współczesnym, powojennym świecie - wojna miała wszak dowieść antyludzkiego wymiaru przypisywanej realistom zasady „cel uświęca środki”. Środowiska te miały proweniencję częstokroć idealistyczna, co nie mogło pozostać bez wpływu na ich myśl polityczną. Publicyści zamieszczający swoje teksty na łamach „Tygodnika Powszechnego" pragnęli być przede wszystkim rozumnymi realistami, nieodrzucającymi dodatnich stron romantyzmu i liczącymi się z uczuciami narodu, ale przede wszystkim przekonującymi go do racjonalnego pojmowania rzeczywistości politycznej. Wynikało to $z$ przyjmowanej przez to środowisko koncepcji neopozytywizmu. $Z$ pewnościa wojenna trauma sprzyjała też powstaniu narracji skrajnie nawet nie realistycznych, ale pacyfistycznych, odrzucających w ogóle sens kultu walki zbrojnej w narodach, jak polski, małych i słabych. Trudno było natomiast odnaleźć artykuły wprost broniące decyzji o rozpoczęciu walki powstańczej w Warszawie, odnieść można wrażenie, że im więcej lat upływało od sierpniowego zrywu, tym opinie były bardziej krytyczne. $Z$ pewnością nad wszystkimi tymi ocenami rozciagał się cień sowieckiej hegemonii i świadomość geopolitycznych uwarunkowań. Nakazały one wielu niegdysiejszym „mocarstwowcom”, „żołnierzom Imperium" przewartościować swoje postrzeganie Polski w świecie, a przez to także jej dziejów. Jak jednak dowodzi powyższa analiza, nie zawsze oznaczało to przyjęcie całkowicie ugodowych pogladów. Publicyści grup katolickich uważali, że Polska, nawet mimo swej powojennej słabości, może wyciagając wnioski $z$ narodowej przeszłości, poprawić nieco swoje położenie, ale i znacząco je pogorszyć, decydując się na (był to wniosek niezwerbalizowany, ale sugerowany) antysowieckie powstanie. Obawa przed nim przenikała niemalże wszystkie narracje. Nie oznacza to, że całkowicie determinowała ona postrzeganie rzeczywistości, $z$ pewnością jednak, podobnie jak świadomość już zaistniałych strat, skłaniała do ponownego przemyślenia tradycji powstańczej. Czyż jednak publicystyka historyczna może być wolna od współczesnych odniesień? I czy o jej użyteczności nie świadczy to, że pozwala ona zrozumieć 
teraźniejszość? W tym kontekście historyczne refleksje środowisk katolickich, wysoce niespójne i kontrowersyjne, były próbą odnalezienia się przez polska inteligencją powojenna w świecie, który był dla niej obcy, ale $z$ którym starała się, wbrew swym niedawnym przekonaniom, wiązać pewne nadzieje.

\section{Bibliografia}

\section{$\dot{\mathbf{Z}}_{\text {RÓDEA ARCHIWALNE }}$}

Archiwum Katolickiego Stowarzyszenia Civitas Christiana w Warszawie

Akta Aleksandra Bocheńskiego

Jak doszło do powstania „Dziś i Jutro”. Dyskusja na łamach „Życia i Myśli” nr II 21975 z udziałem: Aleksander Bocheński, Jan Dobraczyński, Jerzy Hagmajer, Mieczysław Kurzyna, Romuald Szpor" [wersja robocza maszynopisu, tekst nigdy nieopublikowany na łamach prasy Stowarzyszenia „PAX”], sygn. VII A-305.

Instytut Polski i Muzeum im. gen. Sikorskiego w Londynie

Zespół Prezydium Rady Ministrów - Kancelaria

K. Pruszyński, ZSRR wobec wojny i sprawy polskiej. Nowe źródła informacyjne w ZSRR, sygn. PRM.K.23.

Studium Polski Podziemnej w Londynie

Zespół Ministerstwo Spraw Wewnętrznych

Imperium Słowiańskie. Mapa wydana przez Konfederację Narodu Organizację Drużyn Imperium Słowiańskiego, Warszawa 1 X 1941, sygn. MSW.023_1.

\section{$\dot{Z}_{\text {RÓDEA DRUKOWANE }}$}

Przetakiewicz Z., Od ONR-u do PAX-u (wspomnienia), Warszawa 1994.

\section{Publicystyka}

1 sierpnia, „Dziś i Jutro” 1949, R. V, nr 30 (182), s. 1.

A.S., Spór o idee, „Tygodnik Powszechny” 1947, R. III, nr 7 (100), s. 8.

Bocheński A., „Amocklauf”, „Polityka” 1939, R. X, nr 15 (189), s. 1.

Bocheński A., Dzieje głupoty $w$ Polsce. Pamflety dziejopisarskie, Warszawa 1947.

Bocheński A., List do narodowców, „Bunt Młodych” 1935, R. VI, nr 12-13 (79-80), s. 1.

Bocheński A., O dyskusji nad Monte Cassino, „Tygodnik Powszechny” 1946, R. II, nr 45 (86), s. 1, 4-5. 
Bocheński A., Odpowiadam oponentom, „Tygodnik Powszechny” 1947, R. III, nr 7 (100), s. 6-7.

Braun J., Czasy ekstatyczne, „Tygodnik Warszawski” 1948, R. IV, nr 31-32 (140141), s. $1,4$.

Braun J., Polski ideał państwa chrześcijańskiego. W rocznice Konstytucji 3 Maja, „Tygodnik Warszawski” 1947, R. III, nr 18, s. 1-2.

Brus W., Wojny, których nie było i których nie planowano, „Tygodnik Powszechny” 1947, R. III, nr 24 (117), s. 4-6.

Cyprian T., Sawicki J., Polityka zagraniczna dwudziestolecia, „Tygodnik Powszechny" 1946, R. II, nr 49 (90), s. 7.

dezet, Rocznica nieprzemyślanego czynu, „Słowo Powszechne” 1949, R. III, nr 22 (656), s. 2.

Dobraczyński J., Hierarchia bohaterstwa, „Słowo Powszechne” 1949, R. III, nr 121 (756), s. 1.

Dobraczyński J., O charakterze narodowym, „Tygodnik Warszawski” 1945, R. I, nr 1 , s. 3.

Dobraczyński J., W czwarta rocznicę, „Słowo Powszechne” 1949, R. III, nr 16 (650), s. 1.

Gołubiew A., Myśli o powstaniu warszawskim, „Tygodnik Powszechny” 1946, R. II, nr 31 (72), s. 1-2.

Horodyński D., Dzień Żałoby, „Dziś i Jutro” 1948, R. IV, nr 31 (140), s. 1.

Horodyński D., O tradycje żotnierska A.K., „Dziś i Jutro” 1945, R. I, nr 4, s. 3-4.

Horodyński D., Płodny pył tamtych dni (impresje rocznicowe), „Dziś i Jutro” 1952, R. VII, nr 36 (354), s. 1.

Horodyński D., Po dziewięciu latach, „Dziś i Jutro” 1953, R. IX, nr 31 (401), s. 1. Horodyński D., W tragiczna rocznice, „Dziś i Jutro” 1946, R. II, nr 20 (36), s. 2-3. J.H. [J. Hagmajer], Dr. Jekyll imr. Hyde, „Dziś i Jutro” 1946, R. II, nr 9 (15), s. 5. J.H. [J. Hagmajer], Halina Piasecka („Halina”), „Dziś i Jutro” 1946, R. II, nr 43 (49), s. 5.

J.H. [J. Hagmajer], Włodzimierz Pietrzak („Balk”), „Dziś i Jutro” 1946, R. II, nr 43 (49), s. 5.

jas. [P. Jasienica], Polityczna waga heroizmu, „Tygodnik Powszechny” 1946, R. II, nr 46 (87), s. 12.

Jasienica P., „Z bronia u nogi”, „Tygodnik Powszechny” 1946, R. II, nr 37 (78), s. 3-4.

Jasienica P., Cień Machiawela, „Tygodnik Powszechny” 1947, R. III, nr 31 (124), s. $4-5$.

Jasienica P., Dziesięciolecie, „Tygodnik Powszechny” 1949, R. V, nr 35 (233), s. 5. Jasienica P., Honor, „Tygodnik Powszechny” 1946, R. II, nr 13 (54), s. 3.

Jasienica P., Mimo wszystko, „Tygodnik Powszechny” 1947, R. III, nr 6 (99), s. 4. Jasienica P., Nie wolno, „Tygodnik Powszechny” 1946, R. II, nr 50 (91), s. 2.

Jasienica P., Od izolacji do wspólnoty, „Tygodnik Powszechny” 1947, R. III, nr 24 (117), s. 6. 
Jasienica P., Od strony frontu i polityki, „Tygodnik Powszechny” 1946, R. II, nr 47 (88), s. $1,3$.

Jasienica P., Relacje dwóch ambasadorów, „Tygodnik Powszechny” 1947, R. III, nr 14-15, s. 3-4.

Jasienica P., Sprawy września, „Tygodnik Powszechny” 1947, R. III, nr 3 (96), s. 3.

Jasienica P., Warto pogadać, „Tygodnik Powszechny” 1947, R. III, nr 9 (102), s. 4-5.

Jasienica P., Wojny, których nie było, „Tygodnik Powszechny” 1947, R. III, nr 13 (106), s. 1, 3.

Jasienica P., Wrzesień i sierpien, „Tygodnik Powszechny” 1949, R. V, nr 19 (217), s. 1.

Jasienica P., Z prądem historii, „Tygodnik Powszechny” 1946, R. II, nr 18 (59), s. 2.

Jasiński S., Na marginesie powstań polskich, „Dziś i Jutro” 1946, R. II, nr 43 (49), s. 4.

Kętrzyński W., Historyczne perspektywy, „Tygodnik Powszechny” 1945, R. I, nr 28, s. 1-2.

Kętrzyński W., Na tle powstania listopadowego, „Dziś i Jutro” 1946, R. II, nr 1 (7), s. 4.

Kętrzyński W., Problem Wielopolskich, „Dziś i Jutro” 1946, R. II, nr 28 (34), s. 2-3.

Kętrzyński W., Warszawa 1944, „Tygodnik Powszechny” 1945, R. I, nr 21, s. 1.

Kiejstut. Z-ca Komendanta Konfederacji Narodu [J. Hagmajer], [List do Redakcji „Dziś i Jutro”], „Dziś i Jutro” 1946, R. II, nr 7 (13), s. 5.

Kieniewicz S., Prawda margrabiego, „Tygodnik Powszechny” 1946, R. II, nr 32 (73), s. 3-4.

Kirchmayer J., Rozmowa z Pawłem Jasienica, „Tygodnik Powszechny” 1947, R. III, nr 6 (99), s. 3-4.

Kirchmayer W., Bohaterstwo i rozdział kompetencji, „Tygodnik Powszechny” 1946, R. II, nr 49 (90), s. 7-8.

Kisielewski S., O odwiecznym konflikcie polskim (w II rocznice powstania warszawskiego), „Tygodnik Warszawski” 1946, R. II, nr 31 (38), s. 1.

Kisielewski S., Porachunki narodowe (artykuł dyskusyjny), „Tygodnik Powszechny" 1945, R. I, nr 24, s. 2.

Kisielewski S., Przeciw „dwóm frontom”, „Tygodnik Warszawski” 1946, R. II, nr 11 (18), s. 3.

Lewicki M., Co jest prawda, a co chimera, „Tygodnik Powszechny” 1947, nr 7 (100), R. III, s. 6.

Lipecki J. [I. Pannenkowa], Legenda Piłsudskiego, Poznań 1922.

Lis M.W., O realizmie i polityce, „Tygodnik Powszechny” 1947, R. III, nr 7 (100), s. $7-8$.

Lis M.W., Powstanie Warszawskie, „Tygodnik Warszawski” 1947, R. III, nr 31, s. 1. 
Łomień-Trzebiński A., Wymarsz Uderzenia, „Dziś i Jutro” 1946, R. II, nr 6 (12), s. 1.

Łubieński K., List otwarty do Pana Juliusza Łady (Na marginesie notatki $w$ „The Tablet”), „Dziś i Jutro” 1949, R. IV, nr 49 (158), s. 1-2.

Malewska H., Jeszcze o kulcie heroizmu wojennego, „Tygodnik Powszechny” 1947, R. III, nr 10 (103), s. 4.

Malewska H., Realizm?, „Tygodnik Powszechny” 1946, R. II, nr 49 (90), s. 6.

Micewski A., 2-X-1944, „Słowo Powszechne” 1951, R. V, nr 260 (1602), s. 3-4.

Osmańczyk E., Sprawy Polaków, Katowice 1946.

Pannenkowa I., Czy nie za wiele pesymizmu?, „Tygodnik Warszawski” 1946, R. II, nr 35 (42), s. 2-3.

Pannenkowa I., Mentorzy, „Tygodnik Warszawski” 1947, R. III, nr 49 (108), s. 3-4.

Pannenkowa I., Realizm romantyków, "Przegląd Powszechny” 1948, R. LXVI, t. 228 , s. 226-236.

Pannenkowa I., Realizm, bohaterstwo $i$ - bomba atomowa, „Tygodnik Warszawski” 1947, R. III, nr 19, s. 3-4.

Pigoń S., O największym zwycięstwie Tadeusza Kościuszki, „Tygodnik Powszechny” 1946, R. II, nr 12 (53), s. 1.

Piwowarczyk J., „Racja stanu”, „Tygodnik Powszechny” 1947, R. III, nr 38 (131), s. 1.

Pruszyński K., Margrabia Wielopolski, Warszawa 1946.

Pruszyński K., Wobec Rosji, „Wiadomości Polskie” 1942, nr 40, s. 1.

Przetakiewicz Z., Nakaz realizmu. „Krwia polska dowiedźmy światu nasze prawo do niepodległoścl”, „Dziś i Jutro” 1947, R. III, nr 4 (61), s. 1.

Przetakiewicz Z., ONR - Konfederacja Narodu - „Dziś i Jutro”, „Dziś i Jutro” 1947, R. III, nr 14-15 (71-72), s. 7.

Przyjaźń, „Słowo Powszechne” 1950, R. IV, nr 108 (1095), s. 1.

Realizm, „Dziś i Jutro” 1947, R. III, nr 30 (87), s. 1.

Skałkowski A.M., Somosierra, „Tygodnik Powszechny” 1947, R. III, nr 24 (117), s. 7.

Spór o powstanie warszawskie w powojennej publicystyce polskiej 1945-1981, red. D. Gawin, Warszawa 2004.

Stomma S., Maksymalne i minimalne tendencje społeczne katolików, „Znak” 1946, nr 3, s. 257-275.

Straszewski M., Błędy polityki przedwrześniowej, „Tygodnik Powszechny” 1946, R. II, nr 49 (90), s. 7.

Studentowicz K., Sens powstania warszawskiego, „Tygodnik Warszawski” 1948, R. IV, nr 31-32 (140-141), s. 2.

Syrewicz K., Problem źle postawiony, „Tygodnik Powszechny” 1946, R. II, nr 49 (90), s. 7.

Wydra F., Głos żołnierza, „Tygodnik Powszechny” 1947, R. III, nr 7 (100), s. 8.

Zagórski J. Przywara narodowa nr 1, „Tygodnik Powszechny” 1946, R. II, nr 11 (52), s. 1. 
Zaniec T, „Geneza „realizmu” politycznego w Polsce, „Dziś i Jutro” 1954, R. X, nr 4 (426), s. 3.

Zaniec T., Geneza "realizmu” politycznego w Polsce. Mit o Aleksandrze Wielopolskim, „Dziś i Jutro” 1954, R. X, nr 9 (431), s. 3.

Zaniec T., Mit o Aleksandrze Wielopolskim (III), „Dziś i Jutro” 1954, R. X, nr 10 (432), s. 2-3.

Ziembicki Z., Pokolenie dramatyczne, „Dziś i Jutro” 1946, R. II, nr 5 (11), s. 4.

Żur, O nierealnym realiźmie, „Tygodnik Warszawski” 1948, R. IV, nr 10 (119), s. 7.

Żurowski S., Myśli o powstaniu, „Dziś i Jutro” 1950, R. VI, nr 31 (245), s. 1.

\section{OpRacowania}

Bankowicz B., Neopozytywizm Znaku: próba legalizmu motywowana realizmem, [w:] B. Bankowicz, A. Dudek, Ze studiów nad dziejami Kościoła i katolicyzmu w PRL, Kraków 1996, s. 37-52.

Blit L., The Eastern Pretender. Boleslaw Piasecki. His life and times, London 1965.

Bromke A., Poland's politics. Idealism vs Realism, Cambridge 1967.

Dudek A., Pytel G., Bolesław Piasecki. Próba biografii politycznej, Londyn 1990.

Engelgard J., Bolesław Piasecki 1939-1956, Warszawa 2015.

Friszke A., Między wojna a więzieniem 1945-1953. Młoda inteligencja katolicka, Warszawa 2015.

Graczyk R., Spory ideowo-polityczne w kręgu „Tygodnika Powszechnego” w latach 1945-1953, [w:] Temat polemiki: Polska. Najważniejsze polskie spory ideowo-polityczne, red. J. Kloczkowski, Kraków 2012, s. 315-333.

Graczyk R., Stanowisko katolików świeckich z „Tygodnika Warszawskiego”, „Tygodnika Powszechnego" oraz „Dziś i Jutro” wobec władzy i ideologii komunistycznej $w$ latach 1945-1948, [w:] Polskie wizje i oceny komunizmu po 1939 roku, red. R. Łatka, B. Szlachta, Kraków 2015, s. 235-239.

Jaszczuk A., Ewolucja ideowa Bolesława Piaseckiego 1932-1956, Warszawa 2005.

Kierys A., Polska Jasienicy. Biografia publicysty, Kraków 2015.

Kimla P., Historycy-politycy jako źródło realizmu politycznego. Tukidydes - Polibiusz - Machiavelli, Kraków 2009.

Kloczkowski J., Oblicza polskiego realizmu politycznego, [w:] Realizm polityczny. Przypadek Polski. Wybór tekstów, red. J. Kloczkowski, Kraków 2008, s. 7-15.

Kristanova E., Książka na łamach katolickich czasopism społeczno-kulturalnych $w$ Polsce w latach 1945-1953, Łódź 2012.

Kunicki M.S., Between the brown and the red. Nationalism, Catholicism, and communism in twentieth-century Poland. The politics of Bolesław Piasecki, Ohio 2012.

Majchrowski J., Geneza politycznych ugrupowan katolickich. Stronnictwo Pracy, grupa „Dziś $i$ Jutro”, Paris 1984.

Matyja R., Państwowość PRL w polskiej refleksji politycznej lat 1956-1980, Kraków-Nowy Sącz 2007.

Mazur M., Antykomunistycznego podziemia portret zbiorowy 1945-1956. Aspekty mentalno-psychologiczne, Lublin-Warszawa 2019. 
Orzełek A., Poszukiwanie modelu realizmu politycznego. Myśl i publicystyka Aleksandra Bocheńskiego, Lublin 2019.

Orzełek A., Recepcja publicystyczna „Dziejów głupoty w Polsce. Pamfletów dziejopisarskich” Aleksandra Bocheńskiego, „Przegląd Nauk Historycznych” 2018, R. XVII, nr 2, s. 203-223.

Pietrow N., Stalinowski kat Polski Iwan Sierow, Warszawa 2013.

Sikorski T., Kulesza M., Niezłomni $w$ epoce fałszywych proroków. Środowisko „Tygodnika Warszawskiego” (1945-1948), Warszawa 2013.

Ariel Orzeeek

Maria CuRIe-SkŁodowska University

\section{Disputes on romantism and historical realism in the Polish lay Catholics' press in the years of 1945-1953}

P olis olish secular Catholics in their press in the first post-war years often dealt with the assessment of Polish national uprisings and the conclusions that could be drawn from them for the present and future. However, these narratives were not only depreciating for anti-Russian uprisings, but tried to understand the motivations of their participants. It has often been written about the need for political realists to consider "realism in relation to the feelings of the nation" but also to shape attitudes towards the rational assessment of political phenomena. Texts that were extremely romantic but also extremely realistic and pacifist were published. The discussions and polemics presented resulted from both disappointment with the results of the war and the failure of their own ideas. Awareness of losses recently suffered by the Polish nation as a result of the implementation of insurgent policy and the conviction that the next uprising could bring disastrous effects for the community had a great impact on their formulation. The most characteristic of the dispute between realists and romantics about the very definition of these concepts, the discussion of "Monte Cassino" in the pages of "Tygodnik Powszechny" proved a certain ideological confusion of journalists, desperate to find themselves in a new reality.

Keywords: journalism, People's Poland, political realism, political thought, romanticism, secular Catholics. 